\title{
Phylogeny Study of Genus Pelvetia in Korea by Internal Transcribed Spacer Sequence (ITS)
}

\author{
Bok Kyu Lee, Man Kyu Huh*, Joo Soo Choi and Sung Hyun Cho ${ }^{1}$ \\ Department of Molecular Biology, Dongeui University, 995 Eomgwangno, Busanjin-gu, Busan 614-714, Korea \\ ${ }^{1}$ Department of Biology, Pennsylvania State University, University Park, PA, USA
}

Received November 19, 2008 / Accepted February 16, 2009

\begin{abstract}
The brown algae, or phaeophytes, are a large group of multicellular algae, including many notable types of seaweed. We analysed intra- and interspecific phylogenic studies within the genus Pelvetia in Korea and compared them with results of both same and different species in GenBank. The sequences for P. babingtonii in Korea were generally similar to those for P. babingtonii AF102957, and the sequences of $P$. siliquosa in Korea were also similar to those of $P$. siliquosa AF102958. Sequence variation within the Pelvetia is mostly due to nucleotide substitutions, although several small indels and some large indels can be found. Another source of sequence divergence is length variation due to stretches of short repeats that occur at the ITS1 or ITS2 in all the Pelvetia. NJ analysis consists mainly of two clades. One of them contains $P$. canaliculata and $P$. limitata, and is sister to the rest of the genus ( $P$. siliquosa, $P$. compressa, and $P$. babingtonii). P. babingtonii is not grouped one clade. In the MP analysis, ten accessions or populations were fully resolved and all accessions from the same species formed with $99 \%$ or $100 \%$ bootstrap supports.
\end{abstract}

Key words : ITS, phylogenic analyses, Pelvetia babingtonii, P. siliquosa

\section{Introduction}

Algae encompass several different groups of usually relatively simple living organisms that capture light energy through photosynthesis, converting inorganic substances into simple sugars using the captured energy [1].

The brown algae or phaeophytes are a large group of multicellular algae, including many notable seaweeds [2]. They play an important role in marine environments. For instance Macrocystis kelp, which may reach $60 \mathrm{~m}$ in length, form prominent underwater forests [3]. Many brown algae, such as Fucus, of which bladder wrack is one species, are found along the seashore and some are used as food. Brown algae belong to a very large group called the heterokonts, most of which are colored flagellates [4].

Brown algae belong to a very large group called the heterokonts, most of which are colored flagellates. Most contain the pigment fucoxanthin, which is responsible for the distinctive greenish-brown color that gives brown algae their name. Brown algae are unique among heterokonts in developing into multicellular forms with differentiated tissues, but they reproduce by means of flagellate spore, which

\section{*Corresponding author}

Tel : +82-51-890-1529, Fax : +82-51-890-1521

E-mail : mkhuh@deu.ac.kr closely resemble other heterokont cells. Genetic studies show their closest relatives are the yellow-green algae.

Any species with a highly structured variation pattern must show different distributions of phenotypic characteristics at different locations. Data drawn from such a population would strongly distort intra-generic taxonomic conclusions, unless allowance is made for the structure [15]. In a taxonomic study, Rice and Chapman [15] showed that they are discrete, and presented some intraspecific variation information to support this conclusion. The form of this variation is examined here in detail, and possible causes of the observed structures are considered.

Brown algae of the Fucaceae dominate the biomass. Many macroalgal species are noted for showing great intraspecific phenotypic variability $[13,17]$. The factors controlling this variation have often been studied, frequently with regard to the relative importance of genetic and environmental influences [17]. However, the structural form of the variability and its expression in geographic space have rarely been considered.

Pelvetia is a brown alga a genus of seaweed that lives in the intertidal zones of rocky shores, found on the Atlantic coasts of Europe and North America [1,5].

In this paper, analyses of the intraspecific molecular variation patterns of Pelvetia babingtonii Korea is first presented. This species is an intertidal brawn seaweed of North Pacific rocky shores. It is suppose that this species have been in- 
troduced from Japan by sea current or entry of ships. We analysed intra- and interspecific phylogenic relationships within genus Pelvetia in Korea and to compare with the results of same and other species in GenBank.

\section{Materials and Methods}

\section{Sample materials}

The genus Pelvetia consists of six species and two varieties; Pelvetia babingtonii, Pelvetia calaliculata var. acutiloba, Pelvetia canaliculata, Pelvetia compressa (formerly Pelvetia fastigiata), Pelvetia galapagensis, Pelvetia siliquosa, Pelvetia wrightii, Pelvetia wrigtii f. babingtonii. Most species of Pelvetia occur in the Pacific except $P$. canaliculata. P. canaliculata occurs exclusively in the Atlantic.

The ITS sequences included in this study were obtained from GenBank. In addition, the ITS sequences of all Korean occurred species were used in this study to compare with the results of same species in the list of GenBank. Table 1 lists the genes, taxa, and GenBank accession numbers. The data and alignments are available on request from the author.

P. babingtonii and P. siliquosa were collected from two populations in Korea (Table 1). Fifteen plants were randomly collected from the each population. The use of exclusively mature plants reduces the effects of age on morphology in the data set, since two species mature when two-years old, following the definitions given by Rice and Chapman [15].

The genomic DNA of the samples was extracted from fresh leaves using the plant DNA Zol Kit (Life Technologies Inc., Grand Island, New York, U.S.A.) according to the manufacturer's protocol.

\section{ITS analysis}

Primer sets of about 20 bases in length were used for PCR analysis. These primers were based on well-characteristic DNA sequences and were designed making use of conserved regions of the $18 \mathrm{~S}$ and $28 \mathrm{~S}$ rRNA genes to amplify the noncoding regions between the ITS1 and ITS2 and 5.8S rRNA gene [21]). The ITS region of each sample was symmetrically amplified by PCR either with the primers ITS5 and ITS4 [21] (Table 2) or with F5 and F4, which we specifically designed for Fucus from a sequence for the small subunit (SSU) of rDNA available for F. gardneri at GenBank (X53987) and on our own sequences for the 59 end of the LSU of Fucus.

PCR materials ( $50 \mu 1$ volume) included $50 \mathrm{ng}$ of genomic DNA, $100 \mathrm{uM}$ of each dNTP, $0.2 \mathrm{uM}$ of each primer, $1 \mathrm{x}$ enzyme buffer, and 2 unit of Taq polymerase. The amplification profile was 28 cycles of $94^{\circ} \mathrm{C}$ for $30 \mathrm{sec}, 42^{\circ} \mathrm{C}$ for $60 \mathrm{sec}, 72^{\circ} \mathrm{C}$ for $60 \mathrm{sec}$, preceded by an initial denaturation at $94^{\circ} \mathrm{C}$ for $90 \mathrm{sec}$ and followed by a final extension at $72^{\circ} \mathrm{C}$ for $5 \mathrm{~min}$.

PCR products were separated on 1.5\% agarose gels and purified using the QIAquick Gel Extraction Kit (QIAGEN). The amplified fragments were cloned into a bluescript vector and sequenced using ABI Prism 377 Sequencer (Applied Biosystem, USA). At least seven individuals' clones of each population were analyzed.

\section{Alignment and phylogenetic analysis}

The chromatogram output for each sample was edited using the software Sequence Navigator 1.0.1 (Applied Biosystems Inc.), and the sequences were manually aligned. To determine the ITS boundaries for the Fucaceae, the flanking sequences of ITS-1 and ITS-2 were aligned with all ITS sequences listed in GenBank that include the flanking sequence for the SSU, the 5.8S, and the LSU genes [19]. The limits of ITS- 1 and ITS- 2 varied among all these sequences; thus, the positions at which a sharp change occurs from a

Table 1. Accessions used in the molecular study of the genus Pelvetia babingtonii including population locations and GenBank accession numbers

\begin{tabular}{llll}
\hline \multicolumn{1}{c}{ Taxon } & \multicolumn{1}{c}{ Code } & \multicolumn{1}{c}{ Geographic origin } & GenBank accession number \\
\hline P. canaliculata & P. canaliculata 953 & Sotra, near Bergen, southern Norway & AF102953 \\
& P. canaliculata 955 & Port St. Mary, Chapel Bay, Isle of Man, USA & AF102955 \\
P. limitata & P. limitata 951 & California, Pigeon Point, San Mateo, USA & AF102951 \\
& P. limitata 952 & Oregon, Boiler Bay, USA & AF102952 \\
P. compressa & P. compressa 956 & California, Pigeon Point, San Mateo, USA & AF102956 \\
P. babingtonii & P. babingtonii 957 & Muroran, Hokkaido, Japan & AF102957 \\
& P. babingtonii Korea & Gijang-gun, Busan, Korea & This study \\
P. siliquosa & P. siliquosa 958 & Shadong Peninsula, China & AF102958 \\
& P. siliquosa Korea & Namhae-gun, Gyeongsangnam-do, Korea & This study \\
\hline
\end{tabular}


Table 2. Synthetic primer sequencing $\left(5^{\prime}-3^{\prime}\right)$ used for the ITS analysis in this study

\begin{tabular}{lll}
\hline \multicolumn{1}{c}{ No. } & \multicolumn{1}{c}{ Primer } & \multicolumn{1}{c}{ Reference } \\
\hline ITS1F & 5'-TCCGTAGGTGAACCTGCGG-3' $^{\prime}$ & White et al. (1990) \\
ITS2 & 5'-GCTGCGTTCTTCATCGATGC-3' $^{\prime}$ & White et al. (1990) \\
ITS3 & 5'-GCATCGATGAAGAACGCAGC-3' $^{\prime}$ White et al. (1990) \\
ITS4R & 5'-TCCTCCGCTTATTGATATGC-3' $^{\prime}$ & White et al. (1990) \\
F1 & 5'-CGCACCTACCGATTGAATGT-3' $^{\prime}$ & Serrato et al. (1999) \\
F2 & 5'-GCGACTTGCAGAATCCAGTG-3' $^{\prime}$ & Serrato et al. (1999) \\
F3 & 5'-ACAGACACTCCGACAAGCAT-3' $^{\prime}$ Serrato et al. (1999) \\
F4 & 5'-CTCTTGCTTGATCGGAGGTC-3' & Serrato et al. (1999) \\
\hline
\end{tabular}

sequence that is conserved across all taxa to a sequence that becomes variable (and vice versa for the 39 ends of the ITS regions) are those most likely to be the real boundaries between the rRNA genes and the spacers, and these were considered as such in this study.

A pairwise alignment was calculated using the ClustalX program. Phylogenetic relationship were estimated by MEGA version 4.1 [20] treating all alignment gaps as missing. A maximum parsimony tree (MP) was inferred using heuristic search, branch-swapping options and tree bisectionreconnection. Confidence values for individual branches were determined by a bootstrap analysis with 100 repeated sampling of the data. In addition, a phylogenetic tree was constructed by the neighbor-joining (NJ) method [18] using the NEIGHBOR program in PHYLIP version 3.57 [7].

\section{Results}

The complete ITS1, 5.8S rRNA coding region, ITS2, and stretch of the $5^{\prime}$ end of the large subunit rRNA coding region were PCR amplified, cloned, and sequenced for the both Korean distributed species, P. babingtonii and P. siliquosa. The aligned data sets for P. babingtonii and P. siliquosa are 949 nucleotides (bp), 933 bp, and 995 bp, respectively (Table 3). The ITS sequences of same and other species in same genus included in this study were obtained from GenBank.

The sequences for P. babingtonii Korea were generally similar to those for P. babingtonii AF102957 and the sequences of $P$. siliquosa in Korea were also similar to those for P. siliquosa AF102958.

Aligned nucleotide sequences of the length of ITS1 were varied within genus Pelvetia varying from 401 in P. babingtonii and P. siliquosa to 486 in P. limitata. Especially, P. siliquosa included 14-72 bp more in the ITS1 than those P. canaliculata. The 5.8S subunit of all taxa of Pelvetia was found to constant of 152-153 bp nucleotides. Aligned nucleotide sequences of the length of ITS2 varied from $271 \mathrm{bp}$ in P. canaliculata AF102955 to 409 bp in P. babingtonii AF102957. P. canaliculata and showed the highest number of different bases between all the sequences studied.

Total alignment length is 1161 positions, of which 273 are parsimony-informative, 51 variable but parsimony-uninformative, and 122 constant characters. The base furtherance of $\mathrm{G}+\mathrm{C}$ content was showed $47 \%-53 \%$, and it is $56 \%-60 \%$ in ITS-2 (Table 3). The base furtherance showed the difference to the by a total taxon (Table 4). A distances matrix as the fraction of sites between two sequences in a multiple alignment among species was used to evaluate relatedness among species (Table 4). The distances between same species ranged from a minimum value of 0.001 between P. siliquosa 958 and P. siliquosa Korea and the maximum value of 0.005 between P. limitata 951 and P. limitata 952.

Alignment of the DNA sequences required adding numerous gaps. Sequence variation within the Pelvetia is mostly due to nucleotide substitutions, although several small indels and some large indels can be found. Another source of sequence divergence is length variation due to stretches of short re-

Table 3. Sizes and GC contents of ITS-1, 5.8S and ITS-2 regions of genus Pelvetia

\begin{tabular}{|c|c|c|c|c|c|c|c|}
\hline \multirow{2}{*}{ Taxon } & \multicolumn{2}{|c|}{ ITS-1 } & \multicolumn{2}{|c|}{$5.8 \mathrm{~S}$} & \multicolumn{2}{|c|}{ ITS-2 } & \multirow{2}{*}{$\begin{array}{c}\text { Total } \\
\text { Length (bp) }\end{array}$} \\
\hline & Length (bp) & GC $(\%)$ & Length (bp) & GC (\%) & Length (bp) & GC (\%) & \\
\hline P. canaliculata 953 & 414 & 53 & 153 & 52 & 383 & 58 & 950 \\
\hline P. canaliculata 955 & 413 & 53 & 153 & 52 & 271 & 59 & 837 \\
\hline P. limitata 951 & 486 & 51 & 152 & 51 & 387 & 56 & 1025 \\
\hline P. limitata 952 & 456 & 52 & 152 & 51 & 387 & 56 & 995 \\
\hline P. compressa 956 & 404 & 48 & 153 & 51 & 398 & 60 & 955 \\
\hline P. babingtonii 957 & 401 & 47 & 153 & 52 & 409 & 60 & 963 \\
\hline P. babingtonii Korea & 402 & 49 & 153 & 52 & 388 & 58 & 933 \\
\hline P. siliquosa 958 & 401 & 47 & 153 & 52 & 385 & 60 & 939 \\
\hline P. siliquosa Korea & 401 & 47 & 153 & 52 & 386 & 59 & 940 \\
\hline
\end{tabular}

The codes of taxon are the same as Table 1. 
Table 4. The distances as the fraction of sites between two sequences in a multiple alignment among species of genus Pelvetia using ITS analysis

\begin{tabular}{|c|c|c|c|c|c|c|c|c|c|}
\hline Taxon & can 953 & can 955 & $\lim 951$ & $\lim 952$ & com 956 & bab 957 & bab Kor & sil 958 & sil Kor \\
\hline P. canaliculata 953 & - & & & & & & & & \\
\hline P. canaliculata 955 & 0.002 & - & & & & & & & \\
\hline P. limitata 951 & 1.258 & 1.267 & - & & & & & & \\
\hline P. limitata 952 & 1.267 & 1.276 & 0.005 & - & & & & & \\
\hline P. compressa 956 & 2.655 & 2.666 & 2.396 & 2.356 & - & & & & \\
\hline P. babingtonii 957 & 2.283 & 2.289 & 2.079 & 2.074 & 0.354 & - & & & \\
\hline P. babingtonii Korea & 2.300 & 2.306 & 2.093 & 2.088 & 0.355 & 0.002 & - & & \\
\hline P. siliquosa 958 & 2.538 & 2.546 & 2.480 & 2.486 & 0.437 & 0.141 & 0.141 & - & \\
\hline P. siliquosa Korea & 2.516 & 2.524 & 2.459 & 2.465 & 2.434 & 0.139 & 0.139 & 0.001 & - \\
\hline
\end{tabular}

The taxon codes of first line are the same as those of first column.

peats that occur at the ITS1 or ITS2 in all the Pelvetia.

Within Pelvetia, P. siliquosa is strikingly different from the others (Table 3). P. canaliculata is occurs the Atlantic was also divergence from the Pacific species of Pelvetia, whereas these differ from each other by only $0.1 \%-1.2 \%$ in their ITS regions. In Pelvetia, the divergence between ITS sequences from different geographic regions is in many cases in the same order of magnitude as the divergence between different species (Table 4). Considerable within-individual variability was detected in P. canaliculata and P. limitata, the species of $P$. babingtonii for which more within-individual sequences were obtained, from several individuals from different geographic regions. In P. babingtonii in Korea, most ITS sequences differed by about $0.1 \%$ from the other ITS sequences determined from the same species in America.

NJ analysis consists mainly of two clades (Fig. 1). One of them contains P. canaliculata and P. limitata, and is sister to the rest of the genus ( $P$. siliquosa, $P$. compressa, and $P$. babingtonii). $P$. babingtonii is not grouped one clade, with the exception of the weakly supported P. babingtonii in Korea (47\%) and section P. compressa (57\%). In the MP analysis,

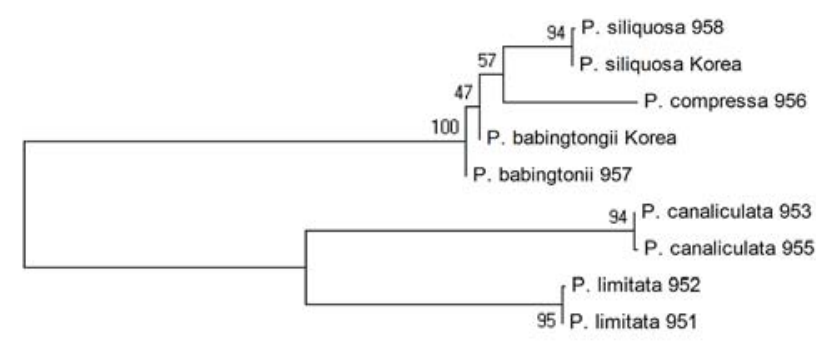

†.2

Fig. 1. Phenogram constructed by the Neighbor-joining method. Numbers on the branches indicate bootstrap proportions (1000 replicates). The codes of taxon are the same as Table 1.

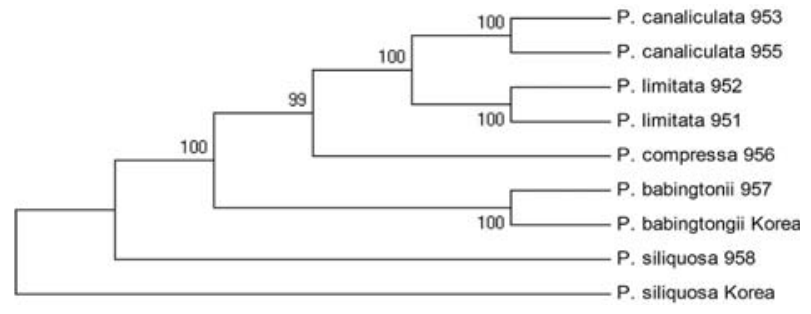

Fig. 2. The most parsimonious tree (using PAUP 4b10, exhaustive search, unweighted parsimony analysis, gaps=fifth state) from the 1161 aligned positions of the initial matrix).

ten accessions or populations were most fully resolved and all populations (accessions) from same species formed with $99 \%$ or $100 \%$ bootstrap support (Fig. 2).

\section{Discussion}

The rubisco spacer sequences give the good resolution at the genus Pelvetia and species level $[10,11]$. Lee [10] worked on the studied rubisco spacer for examining generic relationships with in the Pelvetia (P. babingtonii, P. canaliculata, P. fastgiata, and P. siliquosa) and Pelvetopsis (P. limitata). In its trees, $P$. siliquosa in Korea and P. babingtonii in Japan were grouped into intermost clade and consistent with our results. P. limitata was situated between north Pacific species and European P. canaliculata [10]. However, in this study, P. canaliculata was close to P. limitata (Figs. 1 and 2) Bootstrap analysis strongly supported (100\% for MP) clade of the $P$. canaliculata and P. limitata. Serrato et al [19] also reported that $P$. canaliculata was positioned as the sister group the P. limitata. Lee et al [9] studied phylogenetic relationships of Pelvetia and Pelvetiopsis (Phaerophyceae) based on small subunit ribosomal DNA sequences. They suggested that the genus Pelvetia was not monophytic and the genus 
Pelvetiopsis was not closely related to Pelvetia. However the results were included small subunit (SSU) rDNA sequence data which were varied according to individuals of same species. If the SSU data were excluded from they data, it is very similar to some part of our results (e.g. P. canaliculata is sister to $P$. limitata).

The results for two P. babingtonii and P. siliquosa in Korea using ITS were generally similar to those for P. babingtonii and P. siliquosa in north America. The relationships are illustrated in Figs. 1 and 2. However, P. babingtonii AF102957 and P. babingtonii Korea differed from each other by only the four nucleotydes. This low number of variable sites explains their grouping in the distance analysis and very recent radiation [8]. In Fucaceae, examination of the variance components reveals that about half of the variance was due to within site, individual variation [15]. In addition, the morphometry of Fucus responds to latitude, longitude and exposure, but that these variables can only account for a small part of the variation in the data set. Much of this relates to exposure, which is widely supposed to have a major influence on seaweed phenotypes $[5,16]$. The remainder may be controlled, via latitude and longitude, by clines in sunlight intensity, photoperiod and temperature and by geographic distance leading to restricted gene flow [17].

If widespread extinction of some species (e.g. Fucus. spiralis) of Fucus occurred during the LGM, its modern distribution may result from processes similar to that reported for the intertidal gastropod Nucella in the northeastern Pacific [12]. The patterns are consistent with the hypothesis that high intertidal dwelling Fucus recently colonized the northeastern Pacific following widespread population loss during the last glacial maximum (LGM) due to more exposure to cold temperature stress in air during low tides, a stress that Fucus was able to minimize because of its lower position in the intertidal and which is reflected in higher population structure and diversity.

Recently, Coyer et al [4] reported intra- and inter-specific phylogenetic relationships within the genus Fucus (275 individuals representing 16 taxa) using two regions of the mitochondrion and species of Fucus are considered as the rapidly evolving genus. For example, F. spiralis typically is confined to the high intertidal throughout much of its extant range, it is conceivable that most populations in the North Pacific could not have survived the stress of cold air temperatures during the LGM and subsequent post-LGM recolonization from the few surviving populations in the southern refugia was retarded because of competition with other in- tertidal Fucales (e.g., genera Pelvetia, Hesperophycus, Pelvetiopsis, and Silvetia) and the Gigartinales (intertidal red algae). On the other hand, the mid-to-low intertidal F. distichus was afforded a refuge in depth during the LGM and their persistent existence is revealed by extant high levels of haplotype and nucleotide diversity. This scenario assumes that colonization of the North Atlantic by the F. spiralis ancestor and F. distichus ancestor occurred before the LGM.

We observed a substantial genetic differentiation between morphlotype among genus Pelvetia using Lee's study [10]. Furthermore, populations of the same species revealed a coherent pattern of genetic variation, although widely dispersed populations of common species were influenced by isolation-by-distance effects [14]. Given the rapid fertilization of released oogonia in these algae, varying heights of plants on the shore (and hence times of immersion on a rising tide) may impose considerably greater barriers to interbreeding than their geographic proximity would suggest. Once a zygote is formed, it can probably only be dispersed over limited distances. Nothing is known of the extent of dispersion in Pelvetia spp., but estimates for other macroalgae range from a maximum of three meters (Postelsia palmaeformis) [6] and a mean of five meters (Macrocystis pyrifera) [1]. Thus, the plants appear to form a morphological patchwork or "mosaic"; those within any one "cell" of which are relatively homogeneous. Alternatively, it is possible that the phenotypic variation pattern takes the form of a complex of "micro-clines" in geographic space, including those relating to exposure, or some intermediate involving clinical boundaries to mosaic cells [15]. Thus, it appears probable that sexual reproduction in these species involves a high degree of self-fertilization. The timing of gamete release may further limit gene exchange, albeit not as much as self-fertilization does. Sequently species of Pelvetia are accompany general modes of natural speciation, based on the extent to which speciation and populations are geographically isolated from one another.

\section{Acknowledgment}

This work was supported by Dongeui University Research Grant (2008) for first author.

\section{References}

1. Anderson, E. K. and W. J. North. 1966. In situ studies of spore production and dispersal in the giant kelp 
Macrocystis. Proc. Rot. Seaweed Symp. 5, 73-86.

2. Bergstrom, L., R. B. Jonsson, and L. Kautsky. 2006. Genetic and morphological identification of Fucus radicans sp. nov. (Fucales, Phaeophyceae) in the Brackish Baltic Sea. J. Phycol. 41, 1025-1038.

3. Coyer, J. A., A. F. Peters, W. T. Stam, and J. L. Olsen. 2003. Post-ice age recolonization and differentiation of Fucus serratus L. (Phaeophyceae; Fucaceae) populations in Northern Europe. Mol. Ecol. 12, 1817-1829.

4. Coyer, J. A., G. Hoarau, M. O. Secq, W. T. Stam, and J. L. Olsen. 2006. A mtDNA-based phylogeny of the brown algal genus Fucus (Heterokontophyta; Phaeophyta). Mol. Phylogen. Evol. 39, 209-222.

5. Davison, I. R., L. E. Johnson, and S. H. Brawley. 1993. Sublethal stress in the intertidal zone: tidal emersion inhibits photosynthesis and retards development in embryos of the brown alga Pelvetia fastigiata. Oecologia 96, 483-492.

6. Dayton, P. K. 1973. Dispersion, dispersal, and persistence of the annual intertidal alga, Postelsia palmaeformis Ruprecht. Ecology 54, 433-438.

7. Felsenstein, J. 1993. PHYLIP (Phylogeny Inference Package) version 3.5s, Distributed by the author. Department of Genetics, Univ. Washington, Seattle.

8. Leclerc, M. C., V. Barriel, G. Lecointre, and B. de Reviers. 1998. Low divergence in rDNA ITS sequences among five species of Fucus (Phaeophyceae) suggests a very recent radiation. J. Mol. Evol. 46, 115-120.

9. Lee, W. L., H. S. Yoon, and S. M. Boo. 1998. Phylogenetic relationships of Pelvetia and Pelvetiopsis (Phaerophyceae) based on small subunit ribosomal DNA sequences. J. Plant Biol. 41, 103-109.

10. Lee, Y. K. 1997. Phylogenetic relationships among Pelvetia and Pelvetiopsis species (Fucaceae, Phaeophyta) based on rubisco spacer sequences. Master's thesis, Chungnam National University.

11. Lee, Y. K., H. S. Yoon, T. Motomura, Y. J. Kim, and S. M.
Boo. 1999. Phylogenetic relationships between Pelvetia and Pelvetiopsis (Fucaceae, Phaeophyta) inferred from sequences of the RUBISCO spacer region. Eur. J. Phycol. 34, 205-211.

12. Marko, P. B. 2004. What's larvae to do with it? Disparate patterns of postglacial population structure in two benthic marine gastropods with identical dispersal potential. Mol. Ecol. 13, 597-611.

13. Munda, I. M. 1976. Some aspects of the benthic algal vegetation of the South Icelandic coastal area. Res. Inst. Nedri as Hveragerdi. Icei. Bull. 25, 1-69.

14. Rice, E. L., T. J. Kenchington, and A. R. O. Chapman. 1985. Intraspecific geographic-morphological variation patterns in Fucus distichus and F. evanescens. Marine Biology 88, 207-215.

15. Rice, E. L. and A. R. O. Chapman. 1985. A numerical taxonomic study of Fucus distichus L. emend. Powell (Phaeophyta). J. Mar. Biol. Ass. U.K. 65, 433-459.

16. Russell, G. 1978. Environment and form in the discrimination of taxa in brown algae. pp. 339-369, In Irvine, D. E. G. and J. H. Price (eds.), Modem Approaches to the Taxonomy of Red and Brown Algae, Academic Press, London.

17. Russell, G. and A. H. Fielding. 1981. Individuals, populations and communities. Bot. Monogr. 17, 393-420.

18. Saitou, N. and M. Nei. 1987. The neighbor-joining method: A new method for reconstructing phylogenetic trees. Mol. Biol. Evol. 4, 406-425.

19. Serrao, E. A., L. A. Alice, and S. H. Brawley. 1999. Evolution of the Fucaceae (Phaeophyceae) inferred from nrDNA-ITS. J. Phycol. 35, 382-394.

20. Tamura, K., J. Dudley, M. Nei, and S. Kumar. 2007. MEGA4: Molecular Evolutionary Genetics Analysis (MEGA) software version 4.0. Mol. Biol. Evol. 24, 1596-1599.

21. White, T. J., T. Bruns, S. Lee, and J. Taylor. 1999. Amplification and direct sequencing of fungal ribosomal genes for phylogenetics, pp. 315-322, In Innis M. A., D. H. Gelfand, J. J. Sninsky, and T. J. White (eds.), PCR Protocols: A Guide to Methods and Applications, New York Academic Press.

\title{
초록 : ITS에 의한 한국 내 Pelvetia속 분류군의 계통학적 연구
}

\author{
이복규· 허만규 ${ }^{*}$ 최주수 $\cdot$ 조성현 ${ }^{1}$ \\ (동의대학교 분자생물학과, ${ }^{1}$ 펜실베이니아 주립대학 생물학과)
}

갈조류 모자반과 Pelvetia속은 다세포 조류로 많은 해조류를 포함하고 있으며 북반구 태평양과 대서양에 분포되어 있다. Pelvetia속에 속하는 우리나라의 동종 및 근연한 같은 속내 종에 대해 유전자은행을 통해 밝혀진 ITS에 의한 서열을 이용하여 계통관계를 조사하였다. 한국의 P. babingtonii은 북미의 P. babingtonii AF102957과 유사한 핵산서열 로 계통도 분석에서 같은 분지군을 형성하였다. 한국의 P. siliquosa은 역시 북미의 P. siliquosa AF102958과 유사한 핵산서열로 계통도 분석에서 같은 분지군을 형성하였다. Pelvetia 속 내 여러 종간은 결실이나 삽입에 의한 indel이 많은 반면 같은 종내 계통은 치환에 의한 차이가 현저하였다. 이 속은 NJ분석에서 크게 두 분지군으로 나뉘는데 한 그룹은 P. canaliculata와 P. limitata이며 나머지 그룹은 P. siliquosa, P. compressa, P. babingtonii을 포함하고 있었다. ITS 서열로 한국 내 분류군과 북미 간 분류군이 잘 구분되었다. MP 분석에서도 높은 지지도로 잘 구분되었다. 따라서 ITS 서열로 종 동정에 이용할 수 있었으며, 종의 보전이나 생식질 보전에 기초로 이용될 수 있을 것으로 사료된다. 